\title{
PERTUMBUHAN DAN KANDUNGAN ASAM OLEANOLAT RUMPUT MUTIARA (HEDYOTIS CORYMBOSA) PADA BERBAGAI DOSIS PUPUK KANDANG SAPI DAN PUPUK ORGANIK CAIR
}

\author{
G'lora Jayantie ${ }^{1)}$, Ahmad Yunus ${ }^{2)}$, Bambang Pujiasmanto ${ }^{2)}$, Yuli Widiyastuti ${ }^{3)}$, \\ $\left.{ }^{1}\right)$ Mahasiswa Program Studi Agroteknologi Fakultas Pertanian UNS, Surakarta \\ $\left.{ }^{2}\right)$ Staf Pengajar Program Studi Agroteknologi Fakultas Pertanian UNS, Surakarta \\ ${ }^{3}$ ) Staf Balai Besar Penelitian dan Pengembangan Tanaman Obat dan Obat Tradisional \\ Contact Author: glorajayanti@gmail.com
}

\begin{abstract}
Research on the growth and oleanolic acid content of pearl grass (Hedyotis corymbosa) in experimentall field of Medicinal Plants and Traditional Medicines Research and Development Center (B2P2TOOT), Tanjungsari Village, Tegal Gede Village, Karanganyar and B2P2TOOT laboratory, Tawangmangu, Karanganyar. The research has been conducted in August to November 2017. The purpose of this research is to know the dosage of cow manure and liquid organic manure which has the most influence to the growth and the oleanolic acid content of pearl grass. The experiment was designed in a randomized complete block design with twelve treatments and three repication. The observed data analyzed using variance analysis with $5 \%$ level then if there was a significant difference in the continued test with Duncan's Multiple Range Test (DMRT). The results showed that the use of cow manure at doses of $0 \mathrm{~kg}^{-1} \mathrm{~m}^{2}, 4,6 \mathrm{~kg}^{-1} \mathrm{~m}^{2}, 6,1 \mathrm{~kg}^{-1} \mathrm{~m}^{2}$ and $7,6 \mathrm{~kg}^{-1} \mathrm{~m}^{2}$ did not give increase to all observation variables. The use of POC dose $0 \mathrm{ml}^{-1}$ liter, $5 \mathrm{ml}^{-1}$ liter and $10 \mathrm{ml}^{-1}$ liter did not give increase to all observation variables. All given treatments may show that oleanolic acid is present in pearl grasses.
\end{abstract}

Keyword: Organic fertilization, Secondary metabolite, Medicinal plant

AGROTECHNOLOGY RESEARCH JOURNAL

Jayantie G, Yunus A, Pujiasmanto B et al. 2017. Pertumbuhan dan kandungan asam oleanolat rumput mutiara (Hedyotis corymbosa) pada berbagai dosis pupuk kandang sapi dan pupuk organik cair.Agrotech Res J 1(2):13-18. Jayantie G, Yunus A, Pujiasmanto B et al. 2017. Growth and oleanolic acid of pearl grass (Hedyotis corymbosa) at various doses of cow manure and liquid organic fertilizer. Agrotech Res J 1(2): 13-18.

\section{PENDAHULUAN}

Gulma merupakan tumbuhan yang dapat tumbuh dimana saja dalam waktu tertentu dan tidak dikehendaki manusia. Gulma biasanya menjadi sebuah masalah yang cukup besar dalam teknik budidaya suatu tanaman. Menurut Soerjani et al. (1996) kebutuhan untuk mengendalikan gulma mencapai 25$30 \%$ dari biaya produksi sehingga meningkatkan kebutuhan biaya pada budidaya. Dibalik kekurangannya tersebut, gulma sebenarnya juga memilki manfaat diantaranya sebagai tanaman obat.

Salah satu contoh gulma yang berkhasiat sebagai tanaman obat adalah rumput mutiara. Rumput mutiara merupakan tumbuhan herba yang tumbuh pada lingkungan dengan kondisi cukup air. Tumbuhan ini banyak ditemukan disisi jalan dan tidak banyak dimanfaatkan oleh masyarakat. Tumbuhan ini memiliki banyak kandungan diantaranya asam ursolat dan asam oleanolat. Asam ursolat dan asam oleanolat berperan untuk mencegah pembelahan sel kanker menjadi lebih ganas (Sirait 2014). Tanaman ini dapat dikonsumsi dengan cara dikeringkan terlebih dahulu (Soemardji et al. 2015).

Kendala yang dialami tumbuhan rumput mutiara ini adalah masyarakat belum banyak membudidayakan karena tumbuhan ini dianggap gulma dan tidak memiliki manfaat. Salah satu teknik budidaya pertanian yang mampu meningkatkan pertumbuhan adalah dengan pemupukan. Pemupukan dengan menggunakan pupuk organik lebih disarankan karena pupuk organik dapat memperbaiki kesuburan tanah dan tidak meninggalkan residu pada tanah sehingga dapat menjaga kualitas tanah tempat budidaya (Roidah 2013). Menurut Yusron et al (2007) penggunaan pupuk organik dapat meningkatkan pertumbuhan pada sambiloto.

Salah satu pupuk organik yang biasa digunakan adalah pupuk kandang dan pupuk organik cair (POC). Pupuk kandang dapat menambah tersedianya unsur hara bagi tanaman dan dapat memacu pertumbuhan vegetatif tanaman (Harahap 1993 cit. Syawal 2009). Menurut Roidah (2013) pupuk kandang sapi mengandung unsur $\mathrm{N} 0,29 \%, \mathrm{P} 0,17 \%$ dan $\mathrm{K} 0,35 \%$. Menurut Agustina (2014) penambahan pupuk kandang dan POC mampu meningkatkan pertumbuhan tanaman.

Budidaya rumput mutiara masih sangat jarang dilakukan karena masih sedikit masyarakat yang mengetahui manfaatnya. Mengingat pentingnya manfaat yang dihasilkan pada tanaman ini, maka perlu dilakukan penelitian lebih lanjut untuk dapat meningkatkan pertumbuhan dan kandungan asam oleanolatnya. Hasil dari penelitian ini diharapkan dapat memberikan informasi mengenai dosis penggunaan pupuk kandang dan POC yang tepat sehingga dapat digunakan dalam teknik budidaya. 


\section{BAHAN DAN METODE}

Penelitian pertumbuhan dan kandungan asam oleanolat rumput mutiara (Hedyotis corymbosa) in dilaksanakan pada lahan percobaan Balai Besar Penelitian dan Pengembangan Tanaman Obat dan Obat Tradisional ( $\mathrm{B}_{2} \mathrm{P}_{2}$ TOOT $)$ di Tegal Gede, Kecamatan Matesih, Karanganyar dan Laboratorium $\mathrm{B}_{2} \mathrm{P}_{2}$ TOOT, Tawangmangu, Karanganyar. Penelitian dilaksanakan bulan Agustus hingga November 2016. Bahan yang digunakan dalam penelitian ini adalah bibit rumput mutiara, pupuk kandang sapi, pupuk organik cair (POC), mulsa hitam perak, methanol, dan larutan pengembang. Alat yang digunakan ember, sprayer, cangkul, cetok, papan nama, kawat, penggaris, Thin Layer Chromatography (TLC) densitometer, botol reagent, cawan porselen, waterbath, oven, pipet, chamber dan kertas saring.

Penelitian ini dilakukan dengan menanam bibit rumput mutiara pada lahan percobaan dengan pemberian dosis pupuk kandang sapi $0 \mathrm{~kg}^{-1} \mathrm{~m}^{2}, 4,6 \mathrm{~kg}$ ${ }^{1} \mathrm{~m}^{2}$ (setara 15 ton $^{-1} \mathrm{ha}$ ), $6,1 \mathrm{~kg}^{-1} \mathrm{~m}^{2}$ (setara 20 ton $^{-1} \mathrm{ha}$ ), $7,6 \mathrm{~kg}^{-1} \mathrm{~m}^{2}$ (setara 25 ton $^{-1}$ ha) dan aplikasi POC dengan dosis $0 \mathrm{ml}^{-1}$ liter, $5 \mathrm{ml}^{-1}$ liter, $10 \mathrm{ml}^{-1}$ liter. Variabel yang diamati adalah pertumbuhan dan produksi tanaman yang meliputi tinggi tanaman, jumlah cabang, panjang akar, berat segar tanaman, berat kering tanaman dan kandungan asam oleanolat. Penelitian menggunakan Rancangan Acak Kelompok Lengkap (RAKL) split plot, kemudian data dianalisis menggunakan sidik ragam dengan taraf $5 \%$ kemudian apabila terdapat perbedaan yang nyata dilakukan uji lanjut dengan Duncan's Multiple Range Test (DMRT).

\section{HASIL DAN PEMBAHASAN}

\section{Tinggi tanaman}

Tinggi tanaman merupakan parameter yang paling sering digunakan untuk mengetahui pertumbuhan dan pengaruh suatu perlakuan terhadap hasil tanaman. Penambahan tinggi tanaman dapat dipengaruhi oleh faktor lingkungan, fisiologi dan genetik tanaman. Menurut Sitompul dan Guritno (1995) tinggi tanaman merupakan ukuran pertumbuhan yang paling mudah untuk diamati.

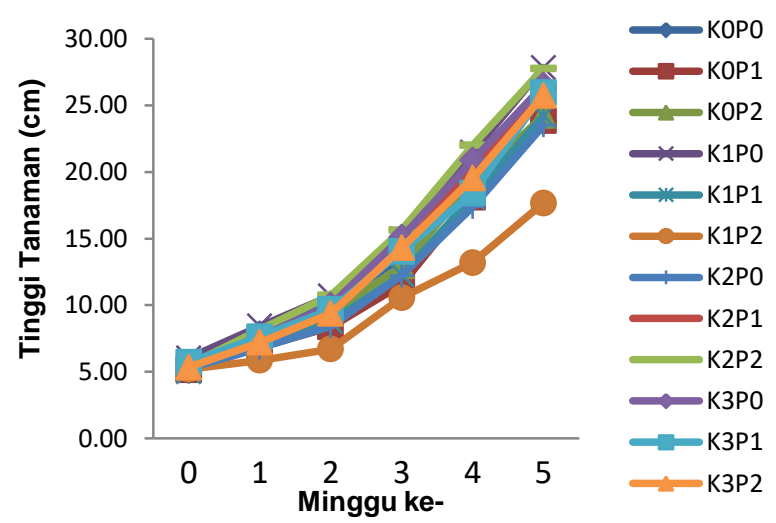

Gambar 1 Grafik tinggi tanaman selama 5 minggu

Berdasarkan gambar 1 diketahui bahwa pertumbuhan tanaman paling baik dipengaruhi oleh perlakuan $\mathrm{K}_{1} \mathrm{P}_{0}$ yaitu kombinasi pupuk kandang $4.6 \mathrm{~kg}$ ${ }^{1} \mathrm{~m}^{2}$ dan tanpa POC dengan tinggi $27,83 \mathrm{~cm}$. Kombinasi perlakuan $\left(\mathrm{K}_{1} \mathrm{P}_{2}\right)$ pupuk kandang $4,6 \mathrm{~kg}^{-1} \mathrm{~m}^{2}$ dan POC $10 \mathrm{ml} /$ liter menghasilkan tinggi tanaman yang paling rendah. Rata-rata pertumbuhan tanaman tiap kombinasi perlakuan tidak memiliki perbedaan yang signifikan.

Tabel 1 Pengaruh bebagai dosis pupuk kandang pada tinggi tanaman

\begin{tabular}{lr}
\hline $\begin{array}{l}\text { Dosis Pupuk Kandang } \\
\left(\mathrm{kg}^{-1} \mathrm{~m}^{2}\right)\end{array}$ & Tinggi Tanaman (cm) \\
\hline 0 & $23,91 \mathrm{a}$ \\
4,6 & $23,96 \mathrm{a}$ \\
6,1 & $25,84 \mathrm{a}$ \\
7,6 & $26,06 \mathrm{a}$ \\
\hline
\end{tabular}

Keterangan : Angka yang diikuti huruf yang sama menunjukkan tidak ada beda nyata pada uji DMRT taraf $5 \%$

Hasil analisis ragam menunjukkan bahwa perlakuan dosis pupuk kandang dan POC tidak berpengaruh nyata pada tinggi tanaman. Pada tabel 1 dapat dilihat bahwa tumbuhan yang paling tinggi adalah tumbuhan dengan perlakuan pupuk kandang dosis $7,6 \mathrm{~kg} / \mathrm{m}^{2}$. Pada penggunaan pupuk kandang ini terdapat kecenderungan bahwa semakin besar dosis pupuk kandang yang diberikan maka semakin meningkat tinggi tanaman. Bahan organik yang sudah terdekomposisi dengan sempurna akan lebih mudah diserap oleh akar tanaman, dengan begitu pertumbuhan tanaman akan lebih baik dibandingkan tanaman yang tidak diberikan pupuk kandang (Hakim 2006).

Tabel 2 Pengaruh beberapa dosis pupuk organik cair pada tinggi tanaman

\begin{tabular}{lr}
\hline Dosis POC $\left(\mathrm{ml}^{-1}\right.$ liter $)$ & Tinggi tanaman $(\mathrm{cm})$ \\
\hline 0 & $25,31 \mathrm{a}$ \\
5 & $25,67 \mathrm{a}$ \\
10 & $23,85 \mathrm{a}$ \\
\hline
\end{tabular}

Keterangan : Angka yang diikuti huruf yang sama menunjukkan tidak ada beda nyata pada uji DMRT taraf 5\%

Hasil analisis ragam menunjukkan bahwa dosis POC tidak berpengaruh terhadap tinggi tanaman dimana tinggi tanaman berkisar antara 23.85-25.67 $\mathrm{cm}$. Hal ini diduga karena unsur $\mathrm{N}$ yang ada didalam tanah sedang, sehingga penambahan unsur $\mathrm{N}$ melalui pemupukan tidak terlihat. Pemberian pupuk organik cair dapat meningkatkan unsur hara N (Isrun 2009). Penyediaan unsur $\mathrm{N}$ dapat membantu meningkatkan tinggi tanaman (Zein dan Leilani 2008).

\section{Jumlah cabang}

Cabang yang diamati adalah cabang primer. Menurut Santoso et al. (2008) menyatakan bahwa pertambahan jumlah cabang primer semakin meningkat seiring bertambahnya umur tanaman. Menurut Pujiasmanto et al. (2009) menyatakan bahwa penambahan jumlah cabang primer sambiloto cenderung mirip dengan penambahan tinggi tanaman. 


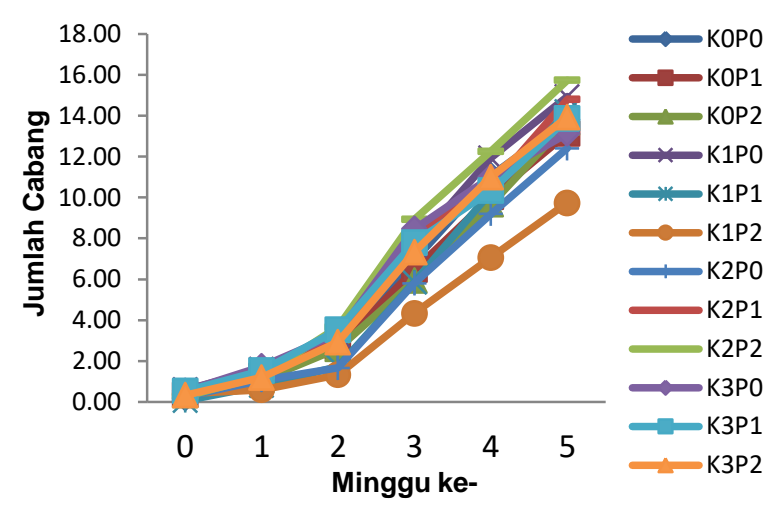

Gambar 2 Grafik jumlah cabang selama 5 minggu

Pada gambar 2. dapat diketahui bahwa jumlah cabang yang paling banyak didapat dari hasil perlakuan $\mathrm{K}_{2} \mathrm{P}_{2}$ yaitu dosis pupuk kandang $6,1 \mathrm{~kg} / \mathrm{m}^{2}$ dan $\mathrm{POC} 10$ $\mathrm{ml} /$ liter air. Jumlah cabang yang paling sedikit ditunjukkan pada kombinasi perlakuan pupuk kandang $4,6 \mathrm{~kg}^{-1} \mathrm{~m}^{2}$ dan POC $10 \mathrm{ml} / \mathrm{liter}$ air. Seperti halnya pada tinggi tanaman, jumlah cabang rumput mutiara meningkat setelah 2 MST.

Tabel 3 Pengaruh beberapa dosis pupuk kandang pada jumlah cabang

\begin{tabular}{lr} 
Dosis pupuk kandang $\left(\mathrm{kg}^{-1} \mathrm{~m}^{2}\right)$ & $\begin{array}{r}\text { Jumlah cabang } \\
\text { (buah) }\end{array}$ \\
\hline 0 & $13,00 \mathrm{a}$ \\
4,6 & $12,95 \mathrm{a}$ \\
6,1 & $14,31 \mathrm{a}$ \\
7,6 & $13,64 \mathrm{a}$ \\
\hline
\end{tabular}

Keterangan: Angka yang diikuti huruf yang sama menunjukkan tidak ada beda nyata pada uji DMRT taraf $5 \%$

Penggunaan pupuk kandang sapi tidak berpengaruh nyata terhadap jumlah cabang. Dapat dilihat bahwa penggunaan pupuk kandang sapi $6.1 \mathrm{~kg}^{-1} \mathrm{~m}^{2}$ memiliki hasil yang paling tinggi yaitu 14,31 buah dan hasil yang terendah pada penggunaan pupuk kandang sapi $4,6 \mathrm{~kg}$ ${ }^{1} \mathrm{~m}^{2}$ dengan jumlah cabang sebanyak 12,95 buah. Penggunaan pupuk kandang $6,1 \mathrm{~kg}^{-1} \mathrm{~m}^{2}$ dan $7,6 \mathrm{~kg}^{-1} \mathrm{~m}^{2}$ lebih baik jika dibandingkan dengan tanaman tanpa menggunakan pupuk kandang sapi. Pemupukan harus dilakukan sesuai kebutuhan tanaman, apabila berlebihan maka efisiensi pemupukan tidak akan tercapai sehingga hasil tanaman tidak maksimal (Rizqiana et al. 2006).

Tabel 4 Pengaruh beberapa dosis pupuk organik cair (POC) pada jumlah cabang

\begin{tabular}{lr}
\hline Dosis POC $\left(\mathrm{ml}^{-1}\right.$ lier $)$ & Jumlah cabang (buah) \\
\hline 0 & $13,57 \mathrm{a}$ \\
5 & $13,60 \mathrm{a}$ \\
10 & $13,27 \mathrm{a}$
\end{tabular}

Keterangan: Angka yang diikuti huruf yang sama menunjukkan tidak ada beda nyata pada uji DMRT taraf $5 \%$

Berdasarkan hasil analisis ragam, penggunaan pupuk kandang sapi dan POC tidak berpengaruh nyata terhadap jumlah cabang. Pada tabel 4, penggunaan dosis POC $5 \mathrm{ml} /$ liter memiliki jumlah cabang yang paling banyak yaitu 13,60 buah. Dosis pupuk $10 \mathrm{ml} /$ liter memiliki hasil paling rendah yaitu 13,27 buah. Hal ini diduga dikarenakan kandungan unsur hara yang ada pada tanah sudah tercukupi sehingga pemberian pupuk kandang dan POC tidak memberikan pengaruh yang signifikan pada tanaman. Hal ini tidak sesuai dengan pernyataan Afrilia (2014) bahwa pemberian POC dapat menambah jumlah cabang produktif tanaman karena POC memiliki sifat katalisator sehingga dapat mengoptimalkan tanaman menyerap unsur hara mikro maupun makro yang diberikan.

\section{Panjang akar}

Rumput mutiara memiliki akar tunggang. Menurut Nurhaeni dan Iftitah (2013) sistem perakaran pada akar tunggang dalam dan memiliki percabangan akar. Perakaran yang dalam memiliki keterkaitan dengan aktivitas tanaman untuk mendapatkan air dan unsur hara. Arah pergerakan akar bergantung oleh letak air dan unsur hara yang ada didalam tanah.

Tabel 5 Pengaruh beberapa dosis pupuk kandang sapi pada panjang akar

\begin{tabular}{lr}
\hline Dosis pupuk kandang $\left(\mathrm{kg}^{-1} \mathrm{~m}^{2}\right)$ & Panjang akar $(\mathrm{cm})$ \\
\hline 0 & $13,03 \mathrm{a}$ \\
4,6 & $13,69 \mathrm{a}$ \\
6,1 & $12,83 \mathrm{a}$ \\
7,6 & $12,85 \mathrm{a}$
\end{tabular}

Keterangan: Angka yang diikuti huruf yang sama menunjukkan tidak ada beda nyata pada uji DMRT taraf $5 \%$

Berdasarkan hasil analisis ragam, kombinasi perlakuan pupuk kandang dan POC tidak memberi pengaruh nyata pada panjang akar. Penggunaan pupuk kandang sapi $4,6 \mathrm{~kg}^{-1} \mathrm{~m}^{2}$ memberikan hasil akar yang paling panjang yaitu $13,69 \mathrm{~cm}$. Akar yang paling pendek ditunjukkan oleh tumbuhan yang menggunakan pupuk kandang sapi dengan dosis $6,1 \mathrm{~kg}^{-1} \mathrm{~m}^{2}$ dengan panjang akar $12,83 \mathrm{~cm}$. Menurut Maryam (2009) penggunaan pupuk kandang sapi lebih meningkatkan panjang akar dibandingkan dengan pupuk kandang lain.

Tabel 6 Pengaruh beberapa dosis pupuk organik cair (POC) pada panjang akar

\begin{tabular}{lr}
\hline Dosis POC $\left(\mathrm{ml}^{-1}\right.$ liter $)$ & Panjang akar $(\mathrm{cm})$ \\
\hline 0 & $13,30 \mathrm{a}$ \\
5 & $13,18 \mathrm{a}$ \\
10 & $12,82 \mathrm{a}$ \\
\hline
\end{tabular}

Keterangan: Angka yang diikuti huruf yang sama menunjukkan tidak ada beda nyata pada uji DMRT taraf $5 \%$

Penggunaan POC dengan dosis $10 \mathrm{ml} / \mathrm{iter}$ memberikan hasil paling pendek yaitu $12,82 \mathrm{~cm}$ sedangkan tanaman tanpa POC memberikan hasil yang paling panjang yaitu $13,30 \mathrm{~cm}$. Hal ini tidak sesuai dengan pernyataan Rizqiani et al. (2006) bahwa tanaman yang diberi POC memiliki akar yang lebih panjang dibandingkan tanpa menggunakan POC. Hal ini berpengaruh terhadap volume akar dimana semakin besar volume akar maka jangkauan akar semakin luas sehingga pengambilan air dan unsur hara dalam tanah semakin maksimal. Rosmarkam dan Yuwono (2002) 
menyatakan semakin panjang dan semakin banyak akar rambut maka semakin banyak unsur hara yang dapat diserap oleh tanaman.

\section{Berat segar tanaman}

Berat segar merupakan berat keseluruhan dari suatu tanaman. Berat segar ini sering digunakan untuk mengetahui tingkat pertumbuhan tanaman. Berat basah tanaman merupakan berat keseluruhan bagian tanaman setelah dipanen sebelum kehilangan air dan kemudian layu (Lakitan 1996). Menurut Sitompul dan Guritno (1995) berat segar dipengaruhi oleh kandungan air yang ada pada keseluruhan tanaman, dimana kandungan air ini dipengaruhi oleh kondisi lingkungan tanaman.

Tabel 7 Pengaruh beberapa dosis pupuk kandang sapi pada berat segar tanaman

\begin{tabular}{lr}
\hline Dosis pupuk kandang $\left(\mathrm{kg}^{-1} \mathrm{~m}^{2}\right)$ & Berat segar (gram) \\
\hline 0 & $8,46 \mathrm{a}$ \\
4,6 & $8,42 \mathrm{a}$ \\
6,1 & $12,94 \mathrm{a}$ \\
7,6 & $9,93 \mathrm{a}$
\end{tabular}

Keterangan : Angka yang diikuti huruf yang sama menunjukkan tidak ada beda nyata pada uji DMRT taraf $5 \%$.

Hasil analisis ragam menunjukkan penggunaan dosis pupuk kandang berpengaruh nyata terhadap berat segar tanaman. Penggunaan dosis pupuk kandang $6,1 \mathrm{~kg}^{-1} \mathrm{~m}^{2}$ memberikan hasil yang paling tinggi dibandingkan dengan dosis pupuk kandang lain yaitu sebesar 12,94 gram. Penggunaan dosis pupuk kandang $4,6 \mathrm{~kg}^{-1} \mathrm{~m}^{2}$ menghasilkan berat segar paling rendah yaitu 8,42 gram. Menurut Muharram (2017) perbedaan hasil pada berat segar dapat disebabkan karena pengaruh bahan organik dimana bahan organik ini dapat mempengaruhi fotosintat sehingga akan meningkatkan berat segar tanaman. Berat segar tanaman juga dipengaruhi oleh kadar air yang diserap dimana semakin banyak air yan diserap maka semakin tinggi berat segar tanaman.

Tabel 8 Pengaruh beberapa dosis pupuk organik cair (POC) pada berat segar tanaman

\begin{tabular}{lr}
\hline Dosis POC (ml ${ }^{-1}$ liter) & Berat segar (gram) \\
\hline 0 & $10,46 \mathrm{a}$ \\
5 & $11,22 \mathrm{a}$ \\
10 & $8,14 \mathrm{a}$
\end{tabular}

Keterangan : Angka yang diikuti huruf yang sama menunjukkan tidak ada beda nyata pada uji DMRT taraf $5 \%$.

Pemberian POC tidak memberikan pengaruh nyata terhadap berat segar. Pada tabel dapat dilihat bahwa penggunaan POC dengan dosis $5 \mathrm{ml}^{-1}$ liter menghasilkan berat segar paling tinggi yaitu 11,22 gram. Dosis POC yang menghasilkan berat segar paling rendah ditunjukkan pada dosis $10 \mathrm{ml}^{-1}$ liter air dengan 8,14 gram. Menurut Syafa'at et al. (2015) menyatakan bahwa besar kecilnya ukuran bagian tanaman berpengaruh terhadap berat segar tanaman karena ukuran dari suatu tanaman mencerminkan seberapa besar penyerapan nutrisi yang dibutuhkan oleh tanaman tersebut.

\section{Berat kering tanaman}

Berat kering dapat digunakan sebagai acuan pengukuran pertumbuhan tanaman. Menurut Pratiwi (2011) semakin besar berat kering yang dihasilkan maka semakin baik metabolisme pada tanaman tesebut, begitu pula sebaliknya. Semakin kecil berat kering maka proses metabolisme pada tanaman tersebut kurang baik.

Tabel 9 Pengaruh beberapa dosis pupuk kandang sapii pada berat kering tanaman

\begin{tabular}{lr}
\hline Dosis pupuk kandang $\left(\mathrm{kg}^{-1} \mathrm{~m}^{2}\right)$ & Berat kering (gram) \\
\hline 0 & $4,51 \mathrm{a}$ \\
4,6 & $4,64 \mathrm{a}$ \\
6,1 & $4,89 \mathrm{a}$ \\
7,6 & $5,57 \mathrm{a}$ \\
\hline
\end{tabular}

Keterangan : Angka yang diikuti huruf yang sama menunjukkan tidak ada beda nyata pada uji DMRT taraf $5 \%$.

Berdasarkan hasil analisis ragam menunjukkan bahwa penggunaan pupuk kandang sapi dan POC dengan berbagai dosis tidak berpengaruh nyata terhadap berat kering. Penggunaan pupuk kandang sapi dengan dosis $7,6 \mathrm{~kg}^{-1} \mathrm{~m}^{2}$ memiliki hasil yang paling tinggi yaitu 5,57 gram. Jika diamati hasil analisis memiliki kecenderungan semakin banayak penggunaan pupuk kandang sapi maka semakin besar berat kering. Pardono (2009) menyatakan bahwa penggunaan pupuk yang sesuai seperti macam, dosis, waktu dan cara yang tepat akan meningkatkan hasil tanaman secara kualitas maupun kuantitas. Pemberian pupuk kandang mampu memperbaiki sifat fisika, kima dan biologi menjadi lebih sesuai untuk pertumbuhan dan perkembangan tanaman.

Tabel 10 Pengaruh beberapa dosis pupuk organik cair (POC) pada berat kering tanaman

\begin{tabular}{lr}
\hline Dosis POC (ml/liter) & Berat kering (gram) \\
\hline 0 & $5,09 \mathrm{ab}$ \\
5 & $5,29 \mathrm{~b}$ \\
10 & $4,33 \mathrm{a}$
\end{tabular}

Keterangan : Angka yang diikuti huruf yang sama menunjukkan tidak ada beda nyata pada uji DMRT taraf $5 \%$.

Jika dilihat dari grafik, dosis POC $5 \mathrm{ml}^{-1}$ liter air menghasilkan berat kering paling tinggi yaitu 5,29 gram. Penggunaan dosis $5 \mathrm{ml}^{-1} \mathrm{I}$ lebih tinggi dari kontrol, perbedaannya sebesar $0,20 \mathrm{gram}$. Dosis $\mathrm{POC} 10 \mathrm{ml}^{-}$ ${ }^{1}$ liter air menghasilkan berat yang paling rendah yaitu 4,33 gram. Kurniawan (2015) menyatakan bahwa pertambahan berat tanaman dan berat kering tanaman merupakan salah satu ciri pertumbuhan. Semakin optimal fotosintat maka semakin besar pula berat kering tanaman, karena bahan kering sangat bergantung pada laju fotosintesis. 


\section{Kandungan asam oleanolat}

Menurut Fu et al (2013) asam oleanolat merupakan senyawa triterpenoid yang biasanya terdapat pada buah-buah, sayuran dan tanaman obat. Asam oleanolat ini biasa digunakan di China sebagai obat untuk pengobatan liver, diabetes dan terapi antikanker. Menurut Endriani et al (2015) menyatakan bahwa ekstrak etanol dari sirsak dan rumput mutiara memiliki sifat antikarsinogen.

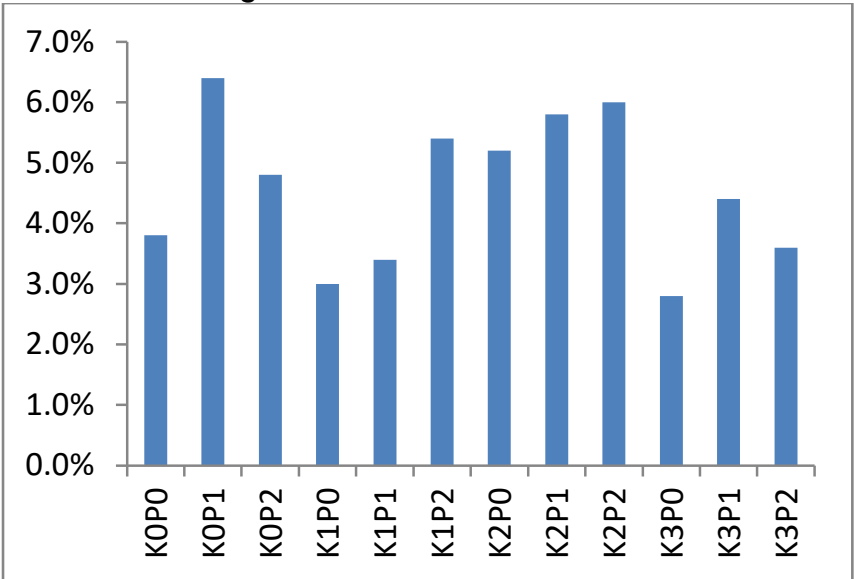

Gambar 3 Grafik rendemen ekstrak total rumput mutiara

Pada gambar 3, kombinasi perlakuan tanpa menggunakan pupuk kandang sapi $\left(\mathrm{K}_{0}\right)$ dan POC 5 $\mathrm{ml} /$ liter $\left(P_{1}\right)$ menunjukkan hasil rendemen ekstrak total paling tinggi yaitu sebesar $6,4 \%$. Rendemen ekstrak total yang dihasilkan rumput mutiara berwarna hijau muda, hijau tua hingga hijau kehitaman. Hal ini seperti hasil analisis dari Lumbessy et al (2013) bahwa hasil dari ekstrak rumput mutiara dengan penambahan ethanol $80 \%$ menghasilkan rendemen ekstrak sebesar 9,7\% dengan warna hijau kehitaman. Ekstrak total pada rumput mutiara ini dapat digunakan untuk mengetahui kandungan apa saja yang dapat digunakan dan dimanfaatkan.

\begin{tabular}{rrrrrrrrrrrr}
1 & 2 & 3 & 4 & 5 & 6 & 7 & 8 & 9 & 10 & 11 & 12 \\
\hline
\end{tabular}

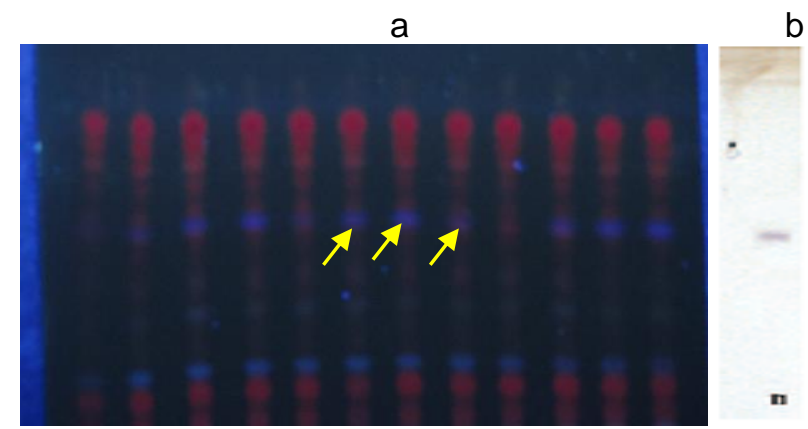

Gambar 4 Hasil kromatografi asam oleanolat dibawah sinar UV 366 nm (a) Standar baku asam oleanolar (b)

Berdasarkan gambar 4, hasil analisis asam oleanolat menggunakan Kromatografi Lapis Tipis (KLT) didapatkan hasil bahwa kandungan asam oleanolat terdapat pada rumput mutiara. Bercak warna yang dihasilkan kemudian dibandingkan dengan nilai $\mathrm{Rf}$ dari standar asam oleanolat. Bercak berwarna ungu yang terlihat menandakan adanya asam oleanolat pada rumput mutiara tersebut. Nilai Rf (Retardation factor) yang dihasilkan dari kombinasi 12 perlakuan hampir sama atau berdekatan sehingga dapat ditarik garis lurus yaitu sebesar 0,41. Menurut Alegantina dan Isnawati (2010) Rf merupakan jarak yang ditempuh oleh senyawa dari titik awal dibagi dengan jarak yang ditempuh oleh pelarut dari titik awal. Oleh karena itu bilangan $\mathrm{Rf}$ selelu lebih kecil dari 1. Hal ini sesuai dengan pernyataan Gambhava et al. (2013) yang menyatakan bahwa nilai $\mathrm{Rf}$ asam oleanolat sebesar 0,41 . Pada penelitian ini digunakan larutan pengembang toluene: etil asetat: asam format dengan perbandingan 8:2:0,1 ml. Kombinasi perlakuan $\mathrm{K}_{1} \mathrm{P}_{2}$ menunjukkan warna yang paling jelas. Perlakuan yang diberikan menunjukkan bahwa terdapat asam oleanolat pada rumput mutiara. Menurut Salim et al. (2016) yang menyatakan bahwa metabolit sekunder dapat dihasilkan pada tumbuhan dengan stress tertentu. Kandungan metabolit sekunder dipengaruhi oleh cekaman lingkungan (Wardani dan Melati 2014). Menurut Gould (2004) metabolit sekunder pada tanaman dipengaruhi oleh berbagai cekaman biotik maupun abiotik. Salah satu cekaman abiotik adalah cekaman hara, misalnya dengan pemberian pupuk (Mualim et al. 2009). Rumput mutiara yang diberikan pupuk nampak memiliki warnayanglebih jelas daripada yang tidak diberi pupuk.

\section{KESIMPULAN}

Berdasarkan hasil penelitian dapat disimpulkan sebagai berikut:

1. Penggunaan pupuk kandang sapi dengan dosis 0 $\mathrm{kg} / \mathrm{m}^{2}, 4,6 \mathrm{~kg} / \mathrm{m}^{2}, 6,1 \mathrm{~kg} / \mathrm{m}^{2}$ dan $7,6 \mathrm{~kg} / \mathrm{m}^{2}$ tidak memberikan kenaikan pada pertumbuhan rumput mutiara

2. Penggunaan $P O C$ dosis $0 \mathrm{ml} /$ liter, $5 \mathrm{ml} /$ liter dan 10 $\mathrm{ml} /$ liter tidak memberikan kenaikan pada pertumbuhan rumput mutiara

3. Kombinasi perlakuan pupuk kandang sapi dosis dosis $0 \mathrm{~kg} / \mathrm{m}^{2}, 4,6 \mathrm{~kg} / \mathrm{m}^{2}, 6,1 \mathrm{~kg} / \mathrm{m}^{2}$ dan $7,6 \mathrm{~kg} / \mathrm{m}^{2}$ dengan pupuk organik cair dosis $0 \mathrm{ml} /$ liter, $5 \mathrm{ml} /$ liter dan $10 \mathrm{ml} /$ liter dapat menunjukkan adanya asam oleanolat pada rumput mutiara

\section{DAFTAR PUSTAKA}

Afrilia TW. 2014. Pengaruh konsentrasi pupuk organik cair dan penggunaan mulsa plastic terhadap pertumbuhan dan hasil tanaman cabai. Prosiding Seminar Nasional "Inovasi Pertanian Spesifik Lokasi” Banjarbaru 6-7 Agustus 2014.

Agustina E. 2014. Pemanfaatan pupuk organik padat dan pupuk organik cair dengan pengurangan pupuk anorganik terhadap pertumbuhan tanaman jagung (Zea mays L.). J Sainstechvol. 6(4):8-15.

Alegantina S, snawati A 2010. Identifikasi dan penetapan kadar senyawa kumarin dalam ekstrak metanol Artemisia annua L. secara kromatografi lapis tipis - densitometri. Bul Penelit Kesehat. 38(1): 17-28.

Endriani S, Suherman, Widiowati W. (2015). Antioxidant activity and anticarcinogenic properties of combination extract of soursop (Annova murica Linn) and pearl grass (Hedyotis corymbosa (L.) 
Lam.). Malaysian J Analiytical Sciences. 19(2): 284290.

Fu LY, Li WX, Xu Y et al. 2013. Repeated oral administration of olenolic acid produces cholestatic liver injury in mice. J Molecules. 18: 3060-3071.

Gambhava NS, Ezhava SB, Rathod IS et al. 2013. Estimation of ursolic acid dan oleanolic acid from leaves of plumeria optusa by HPTLC method after iodine derivatization. J Der Pharma Chemica. 5(3): 44-50

Gould KS. 2004. Nature's swiss army knife: the diverse protective roles of anthocyanins in leaves. J Biomedic Biotechnol. 2004: 314-320.

Hakim N. 2006. Pengelolaan kesuburan tanah masam dengan teknologi pengapuran terpadu. Andalas University Press. Padang.

Isrun 2009. Perubahan status N,P,K tanah dan hasil tanaman jagung manis (Zea mays saccharata sturf) akibat pemberian pupuk organik cair pada entisols. $J$ Agroland. 16(4):281-285.

Kurniawan A. 2015. Pengaruh konsentrasi pupuk pelengkap cair (PPC) terhadap pertumbuhan dan hasil tanaman kacang hijau (Vigna radiate L.). J Inov Pert. 15(2) : 132-144.

Lakitan B. 1996. Fisologi pertumbuhan dan dan perkembangan tanaman. Jakarta (ID): Raja Grafindo Persada.

Lumbessy M, Abidjulu J, Paendong JJE. 2013. Uji total flavonoid pada beberapa tanaman obat tradisional di Desa Waitina Kecamatan Mangoli Timur Kabupaten Kepulauan Sula Provinsi Maluku Utara. J MIPA UNSRAT Online. 2(1): 50-55.

Maryam A. 2009. Pengaruh jenis pupuk organik terhadap pertumbuhan dan hasil panen tanaman sayuran didalam nethouse. Skripsi. Bogor. IPB.

Mualim L, Arifin S, Melati M. 2009. Kajian pemupukan NPK dan jarak tanam pada produksi antosianin daun kolesom. J Agronomi Indonesia. 37(1): 55-61.

Muharam. 2017. Efektivitas penggunaan pupuk kandang dan pupuk organik cair dalam meningkatkan pertumbuhan dan hasil tanaman kedelai (Glycine max L.) varietas anjasmoro di tanah salin. J Agrotek Indon. 2(1): 44-53.

Nurheni W, Iftitah R. 2013. Panjang dan kedalaman akar lateral Jabon (Anthochepalus cadamba (Roxb.) Miq.) di Desa Cibening, Kecamatan Pamijahan, Kabupaten Bogor, Jawa Barat. J Silvikultur Tropika. 4(1): 23-29.

Pardono. 2009. Pengaruh pupuk organik cair air kencing sapi dan pupuk kandang terhadap pertumbuhan dan hasil kacang panjang (Vigna sinensis L.). J Agrosains. 11(1):11-14.

Pratiwi NI. 2011. Pengaruh pupuk kascing dan pupuk organik cair terhadap pertumbuhan dan hasil tanaman caisim (Brassica juncea L.). Skripsi. Surakarta. UNS.

Pujiasmanto B, Sunu P, Toeranto et al. 2009. Pengaruh macam dan dosis pupuk organik terhadap pertumbuhan dan hasil tanaman sambiloto. J IImu dan Agroklimatologi. 6(2): 81-90.

Rizqiani NF, Ambarwati E, Yuwono NW. 2006. Pengaruh dosis dan frekuensi pemberian pupuk organik cair terhadap pertumbuhan dan hasil buncis
(Phaseolus vulgaris L.) dataran rendah. J IImu Pertanian. 13(2):163-178.

Roidah IS. 2013. Manfaat penggunaan pupuk organik untuk kesuburan tanah. Universitas Tulungagung Bonorowo 1(1): 30-42.

Rosmarkam A, Yuwono NW. 2002. Ilmu kesuburan tanah. Jogjakarta (ID): Kanisius.

Salim M, Yahya, Sitorus H et al. 2016. Hubungan kandungan hara tanah dengan produksi senyawa metabolit sekunder pada tanaman duku (Lansium domesticum Corr var Duku) dan potensinya sebagai larvasida. J Vektor Penyakit. 1(1): 11-18.

Santoso BB, Hasnam, Hariyadi et al. 2008. Potensi hasil jarak pagar (Jatropha curcas L.) pada tahun pertama budidaya di lahan kering Lombok Barat, Nusa Tenggara Barat. J Agronomi. 36(2):161-167.

Sirait N. 2014. Potensi rumput mutiara (Hedyotis corymbosa) sebagai antikanker. Warta penelitian dan pengembangan tanaman industry 20(3):11-13.

Sitompul SM, Guritno B 1995. Analisis Pertumbuhan tanaman. Yogyakarta: UGM Press.

Soemardji AA, Anisa N, Damayanti A. 2015. Kajian herba rumput mutiara (Hedyotis corymbosa) sebagai obat. J medicine and health. 1(2):187-199.

Soerjani MM, Soendaru, Anwar C. 1996. Present Status of Weed Problems and Their Control in Indonesia. Biotrop.Special Publication. No 24.

Syafa'at M, Priyono, Ariyanto H. 2015. Pengaruh konsentrasi dan waktu aplikasi pupuk organik cair terhadap pertumbuhan dan hasil tanaman kacang panjang (Figna sinensi L.). J Inov Pert. 15(2): 169181.

Syawal Y. 2010. Dominansi spesies gulma yang berkhasiat obat di kebun percobaan Fakultas Pertanian Universitas Sriwijaya, Inderalaya Ogan Ilir. Prosiding seminar nasional-hasil-hasil penelitian dan pengkajian 13-14 Desember 2010 (pp. 692-703). Palembang: Badan Penelitian dan Pengembangan Daerah Provinsi Sumatera Selatan.

Wardani YE, Melati. 2014. Produksi simplisia dan kandungan bioaktif daun tempuyung (Sonchus arvenis L.) pada berbagai dosis pupuk kandang kambing. J Horti Indon. 5(3): 148-157.

Yusron M, Gusmaini, Januwati M. 2007. Pengaruh polatanam sambiloto - jagung serta dosis pupuk organik dalam alam terhadap produksi dan mutu sambiloto (Andrographis paniculata Nees). J Littri. 13 (4) : 147-154.

Zein A, Leilani I 2008. Pengaruh pupuk organik cair terhadap pertumbuhan kedelai (Glycine max (L.) Merr) padat tanah podzolik merah kuning. $J$ Sainstek. 11(1): 64-6. 